\title{
Media Exposure Among The Children Of Working And Non-Working Mothers In Pakistani Urban Society
}

\author{
Wajiha Raheeq \\ \& \\ Muhammad Arshad \\ Department of Social Work \\ University of Karachi
}

\begin{abstract}
In this study $(\mathrm{n}=250)$ working and non- working mothers were surveyed about the amount of time their kids watch television. These mothers were randomly selected from different schools of Karachi Gulshan-e-Iqbal town. It was investigated whether working and non-working mother spent quality time with their children and what are their preferences once they get back from their workplace. It is observed that technology has made it easier for any child to get engaged and stuck for hours in front of a TV screen. These audiences vary from all ages but children are more exposed to it due to eyecatching sharp images of screen. This study will determine the role of working and stay at home mothers about their control over their kids watching television and their preferable modes of controlling screen time. This study examines maternal control over television viewing and preferable channels watched by a child. The strict maternal behaviour is associated with fewer amounts of television viewing and preferring co-viewing. Those mothers who have strict control over televiewing timings have less psychological problems in their kids and have fewer social issues. Therefore, every mother is quite concerned about her child but her nature of work and job changes her pattern of controlling her kids.
\end{abstract}

Keywords: Working Mother, Non-Working Mother, Televiewing Timings.

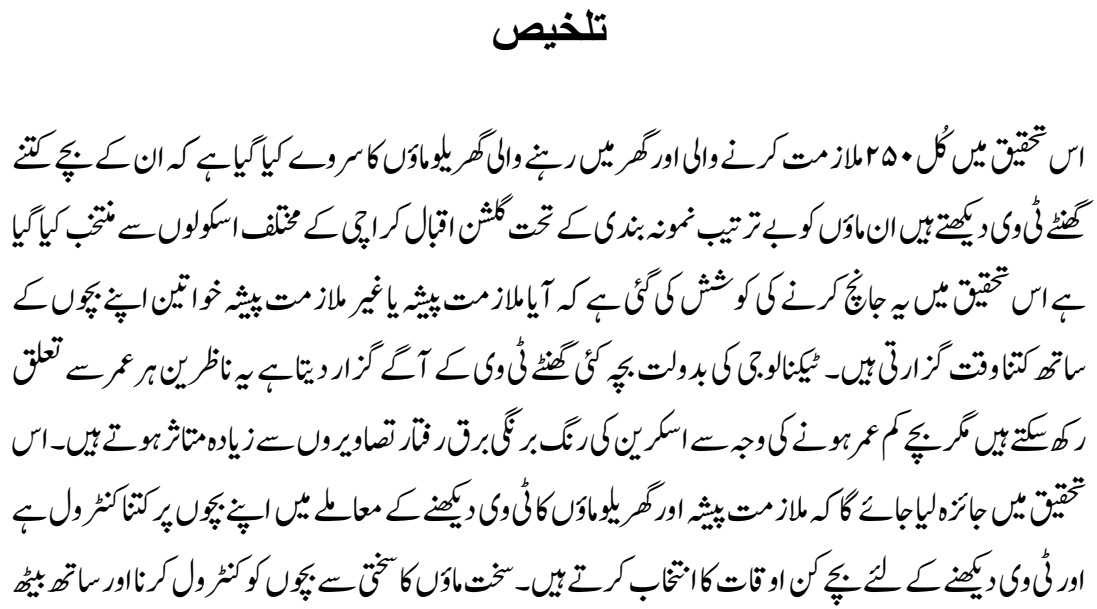




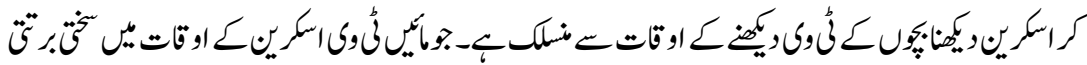

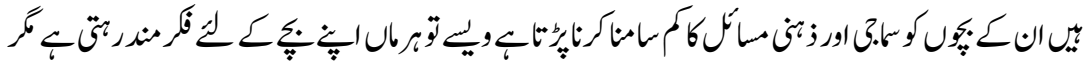

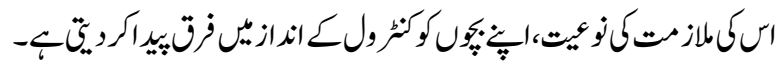

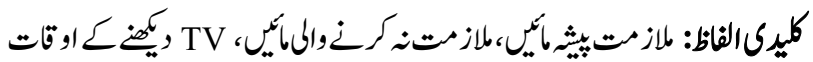

\section{Introduction}

Pakistan is a developing country in which both parents must struggle to live a normal life. They both act as two strong pillars that help your family to grow and improve their status and social expectations socially and economically. This would be very challenging for any partner to run your home and fulfill your desires without your mutual consent and understanding.

Pakistani society is in transformation; city women have entered the era where the public sphere and have greater control of their lives. Family roles for women remain stressed, regardless of the type of work they do. This double housework and professional work burden put tremendous pressure on them Agha, Nadia. (2017).Working Mummies are generally unable to keep track of their kids, what they watch, and how long they watch TV due to the busy workplace and home. Discussions regarding child growth and education for mothers are barely visible in Pakistan. Different individuals have different opinions about the impact of a mother's role on children. Opponents argue that, in early childhood, the relationship between mother and child takes place. It is harmful to separate a mum from work early (Almani, Abro, \& Mugheri, 2012).

After a tiring day from their workplace and many piles of work at the workplace, working women may become exhausted and make it difficult for them to take care of children in household duties. In this case, professional workers, particularly in the mid of their career, where the demands of the family with a child have increased a lot. Child-rearing is itself a complicated task and it becomes tougher accompanied by career growth. It may be difficult to incorporate both without support from the family and the workplace. In some cases, the family and the spouse do not understand the importance of facilitating a woman, though it can be mental, emotional, and psychological support sometimes family provides support by giving a working woman ample space she needs to take care of her family and surrounding members.

The professional mother doing a job may be a member of the Joint Family System or the Nuclear Family System, which requires multiple support. It can affect work-life balance. This balances life is very important for any woman juggling 
between family life and her work. It is the time where one has to understand that household chores are not only the responsibilities of an alone woman who manages to keep a sound relation between her work and family. A supportive husband helps working women to balance their jobs by expressing shared values, and effectively combine work and family life(Essays, 2018).

Numerous problems are faced by growing numbers of working mothers. Its day begins with the dawn. Getting ready for work, making meals for her children, and filling lunch bags. Dropping their children to schools and running to their place of work. All these things sound straightforward, but it is more challenging for a caretaker when juggling responses between the home and the workplace

The question rarely emerges as to whether television is influential but how it affects children and to what extent. It is therefore up to us to analyse closely what is depicted exactly on television and, most specifically, to seek to explore the essence and magnitude of the effect of these images on the perceptual, social, and emotional growth of children of all ages(Einhorn, 1992).

Significantly, stay-at-home moms are relatively straightforward to take full care of their children. Because she is there to satisfy the needs of her children. They can supervise their children carefully, which channels they watch and what their timetable is, she is available to her family 24 hours. She can carefully watch which channels are more suitable for her young ones. Because television has huge potential to divert a child if he or she is playing or studying and also influences her children by her character and social values. Media has become a great influencer and can influence young psychology through its eye-catching sharp images. In contrast, the working mother is often defined as a woman more interested in her career success like having more interest in a lavish lifestyle, a luxury car, a big home, a modern hairstyle, and luxurious clothes than on her own children's success. Such mothers are not as concerned about the relationship they have with their kids, and their attachment level. They become a workaholic and more obsessed with their work nature by getting closer to the positions of worker and mother (Paré \& Dillaway, 2005).

Young people have described several reasons as being correlated with tv consumption. The home and society that surrounds them play a significant role. Children's wellbeing habits, including TV watching, are affected by the parents' values, perceptions, and behaviours. Knowing how parents affect infant watching and physical activity will help to explain transition effectively (Morowatisharifabad, Karimi, \& Ghorbanzadeh, 2015). (Zimmerman \& Christakis, 2005) found Heavy television viewing of children is concerning because of the possible negative effects such viewing could have on cognitive outcomes which have very adverse effects on young children A randomly selected 6-year-old TV 
reduction test showed a modest, but significant, improvement in performance IQ and attention time over 6 weeks on cognitive tasks associated with experimentally induced TV viewing reductions. Heavy television viewing led to many problems that may have long-lasting side effects on a child's growth and development. Strasburger et al., 2010) found that a huge number of the majority of children have access to media in their bedrooms where they are free to watch what they want and parents usually allow them to watch television 7 hours a day. In this regard, the American Academy of Paediatrics has warned a policy regarding young infants of two years of age that they should not be allowed to watch television as they are too young and they could be a target of negative effects of television (Brown, 2011). But in contrast, Ray \& $\mathrm{J}$ at (2010) found that media has both positive and negative sides and it's up to us how we manipulate these side effects into a positive optimistic scenario.

(Ansari \& Crosnoe, 2016)found that in the US, Watching children's television is the most common habit for children. Television is viewed at higher levels and is especially problematic for children with cognitive impairment and aggression. The American Academy of Paediatrics recommends that parents restrict children's TV viewing for 1- 2 hours a day. The number of children watching television is the parents 'behaviour and the parents' behaviour is the reflection of their norms and culture followed in their house. Children of distressed parents watch more television than parents who are not depressed. Parents' well-being and social status are likely to affect children's access to television over time, as well as their behavioural issues. Several studies show parents with social disparities are more vulnerable to outside.

(Welch, 1996) argues that one of the popular forms of parental control linked to the opinion is that, the child gets encouragement from his parents. Children who tend to follow their parents and get engage with them in social and physical activities are more likely to perform better in society. Research has shown that parental exposure has an impact on both what children see on television and how much they see the screen. This is especially important to learn, as most parents do not usually place limits or restraints on children watching TV. This would indicate that parents should have enough knowledge while the child views television; this could have more positive effects on viewing habits than the child viewing alone. Co viewing has some greater extended benefits where a child shares trustworthy boundaries with their parents. He can ask numerous questions while watching television that arises in his little mind. However, studies have found that parental presence or absence typically makes very little difference for one significant point: parents seldom regulate children's viewing. More mothers are currently engaged in marketplace work than ever before, with more than $33 \%$ coming back to work when their child is 3 months old. This article discusses the effect of maternal labour on the child's cognitive growth during the initial months of the 
infant's life. Studies show that this work has adverse impacts in the first year of a child's life. Often, the findings indicate the negative effects of maternal employment in the first quarter of the child's life, where appropriate. When mothers left their children at a very young age, she cannot give her kid full attention love and care that a child deserves. Normally she left her child by hiring anyone to do babysitting for her child. She has no option left to make her child watch television and screen have to babysit a child(Baum II, 2003).

\section{Review of Literature}

With the advent era and millennium, expanded educational opportunities, having better living conditions, and expanded modernization, women living especially in the middle and upper-class backgrounds have also started to emerge from their conventional role as homemakers in entering the workforce. The number of women employed has grown year after year. The growing number of women working in the labour force has created many women in the job market. Women in full-time work, who very often need to stay away from their families for long hours during the day and create more distances from their children. Their children get long distances due to the lack of affection love and care they deserve. Women's jobs created a variety of challenges for their children and opened the way for disputes over maternal job and child growth. There is a general perception that maternal work is promoting social stress to children of school age(Sherlock, 2008).

When mothers are habitual of earning as they are fond of money but not because of need, this creates a situation where money spoils a child in a middle-class family. Early full-time jobs in those households (relative to mothers who did not work outside the home) were associated with a later incidence of infant behavioural problems. This should be recalled, though, that this increased risk was not the case when mothers worked full-time when their children were babies or pre-schoolers. Working full-time when the child is an infant is a special and most critical time in terms of emotional connection between a mother and an infant. A child's emotional needs cannot be fully fulfilled without his motherly presence and affective psychological growth seems to be in danger because it is the crucial time to make a little one more confident individual.

The discovery that there are periods when full-time mothers are at higher risk of depression should not be taken lightly. Researchers also found that their mother's depression strongly affects children. Children of anxious parents have been shown to have problems with self-quieting, slower rates of activity, and reduced desire to participate in different social circles. In contrast, to the children with no depressed parents, mothers living happily with kids, their influence appears to be more positive, having a positive relationship with peers, and decreased level of sadness and rage can be observed. 
The research also found that Mummies working full-time outside, normally spend less time with their kids, but they prefer to swap the amount of time for better quality purpose. Maternal work on average has no impact on time in activities that have a positive influence on the development of children, but it decreases time in types of activities that may be harmful to the development of children. Every week, children whose mothers work full-time spend 3.2 less hours engaged in informal activities that do not require children and parents to engage actively and talk to each other as compared to children whose mothers are unemployed(Ordway, 2018).

Working mothers may cause over-indulgence. Working mothers usually became the reason for of lack self-control in a child because if the mother works for long hours in a day, they will try their best to make their child's precious time more memorable within the limited period of stay together and with less control. For example, many people who had less support because of their parents during their upbringing are too distracted. There is a report that shows working mothers typically have chubbier kids. Working mothers have less care to take care of each part of their children's daily livelihoods, and they can use whatever way their children can be happy to fill their guilty children with not enough time (Hawkes, 2007).

If hardworking will help people succeed, then the spirit of relentlessness and never giving up is the secret to success. When people cannot control themselves, though, they will never succeed entirely. Young children, therefore, need their mothers to stay with them and their personality will be negatively affected by the mothers who always work outside.

Lastly, people usually believe that working moms should have negative influences on their children as an instinct. An experiment has shown that approximately 60 per cent of men and 70 per cent of women agree that the need for self-fulfilment through a woman's work is just as important as the need for the best childcare for her children. Women want to stay with their children and children want to remain with their mothers is human or animal instinct. But all they need is cooperation and the best support system from their family and husband so that they can nurture their kids in the best manner. If people behave in a way that is counter to their nature, then it must at least be a very slight influence on their lives (Leibowitz, 1977) Wrote in his article that educated mother is more involved with their kids as they have fewer kids and use their maternal education on the right path.

For many reasons, however, there are so many studies attempting to demonstrate the opposite outcome of the conventional thinking of people that there is no difference between children with working mothers or not, but few have accepted that working mothers will help their children grow up. Such articles may also be produced by governments or by people who want women to continue to work so 
that social productivity does not decrease. This is simply a valiant supposition, but it still seems possible and reasonable.

\section{Early Child Development}

In fact, due to the basis of the above approaches, working mothers several negative effects on their children such as mother-child barriers usually children hesitate to express their feeling in front of their mothers if a mother is a job freak and a workaholic. Psychological harm to children and excessive self-control of mothers. Moms are often better off spending more time with their children than working for a long time outside(Essays, 2018). Timothy and (Hoffman, Hoffman, \& Youngblade, 1999) found that having a small family size among working mother gives more chance to view television as children don't have more siblings to play with as compared to the large family system where kids get involved in small cost activities including cleaning of house and other house chores(Hoffman et al., 1999).Articulates that it is a normal thinking that a mother's employment can affect a child's development, this is because of the dual responsibility a mother has to perform with a balance between family life and her employment demands. The interaction of a mother also changes with her child while performing employment functions and rearing household activities. Children of school age are mostly away from the home while the parent works. The time that non-working parents spend with their kids is not so much longer than the time so working parents spend with kids. According to earlier studies, highly educated mothers spend more time with children than uneducated mothers. Worked parents can maximize their time with children by changing work(Guryan, Hurst, \& Kearney, 2008).

(Poduval \& Poduval, 2009) found often the effects of maternal jobs on children are positive, and often negative. At 18 months, parents in non-working mother families were happier with their families than those in working mother families were. Infants need to share more joy able moments with their mother, they need a caretaker who can laugh and sing along with them. The motor performance of infants has been positively associated with the number of hours per week and the degree of choice employed. Teenagers whose mothers started work reported declines in psychological distress, which are statistically important. That pattern was strongest because of their anxiety symptoms. Further studies also proved that living in a single-family with working mother would have negative effects on Child's IQ.(Milne et al.,1986).

Can a working mother do justice to both her raising children and her work? It is a very important question in the life of a mother who needs to earn to support her family and perform her duties as a caretaker of her children who are in dire need of love affection from her. The responses vary between a firm yes and a firm no. The answer lies not in the talents or ability of the woman but in her support network. If a woman has a strong support system, she can perform well outside at 
the workplace and at home. Most women left their jobs before their marriages to have better relationships with their in-laws and future husband. She is more concerned about her relationships after marriage a woman who is employed before marriage opts to take a protracted leave to immerse herself entirely in maternity(Poduval \& Poduval, 2009). Scarr et al.,1989 argues that the growing number of mothers in the job field is not surprising when their kids are very young. it depends on every other maternal working mother's background that how their husbands expect them to be or what kind of social support they get from their family system. Motro \& Vanneman, 2015 found in their study that more woman have started to work in the mid-1990s and thus more expectations arise, but in this regard, more lenient policies from government and support from their husband are required this helps them to work more efficiently in their workplaces.

A cross-sectional study reported minor, clear associations between longer maternal work hours and infant weight at 4-5 years of age. Mothers children who worked part-time watched less television and were less likely to become overweight. This is because infants and young children need their mother on their foot to help them eat every after few hours. If she is available at home, she can better manage and track food given to her child this self-results call for family-friendly work practices to encourage healthier behaviours in the workplace (Brown, Broom, Nicholson, \& Bittman, 2010). Numerous studies in the U.S. confirm that the amount of time spent by working parents is less than the amount of time spent by non-working parents, but also assert that while working parents are in school when they are in the working place, the amount of time spent by working and non-working parents is not significantly different (Guryan et al., 2008).

Work habits of married mothers influence the amount of potential human resources that enrich parent-child activities. Mothers in employed-mother households participate with their children in reading/homework activities more often than mothers do in households where the mother is not in jobs. Increased reading and homework practices are found to be correlated with less and higher behavioural issues (Zick, Bryant, \& Österbacka, 2001).

\section{Maternal Control Over Television Viewing}

(Paré \& Dillaway, 2005)found Motherhood and paid jobs are related. Most women retain all social roles at the same time; they have a great capacity to cope at both places work and home. The landscape that binds together the roles of mother and worker is extremely complex and cannot be fully explained. In the life of a mother or paid worker, the public (outside the home) and private (within the home), public and private, do not easily separate. Intensive mothering is described as expertguided, emotionally consuming, labour-intensive, and financially costly. There is no appropriate definition of motherhood. It is a process where each new day taught a new lesson to a woman performing different roles and duties. The mother should be ready at all times with age-appropriate stimulation and interaction to track the 
cognitive and emotional growth of her child care. Excellent mothers devote time, energy, and love for their children. Jordan (2004)found that there are different ways to determine Childs social and cognitive behaviour, as they have very advanced and newer forms of media available. In today's scenario children are prone to an eating disorder, their pro and anti-social behaviours are directly coordinated by their television watching patterns. Their school achievements have major relations with TV watching habits. Drabman \& Thomas (1974) studies showed that children who watched more television are more vulnerable to be aggressive than those who watch less or no violent content.

\section{Methodology}

Research methodology demonstrates the process creation principles used to produce a theory. This is the methodological context in which the analysis is carried out (Mohajan, 2018). The research study is a process of gaining new knowledge in a structured approach requiring careful preparation and strategies to discover or interpret the newly acquired information within a specific designed scientific frame. The validity and reliability of the outcome of a study will depend on the well-designed, accurate, and repeatable procedure with proper conduct, data collection, and logical analysis review. Inappropriate or inaccurate methods may make the analysis unethical, and could even give misleading details to clinicians. Thus it is important to understand the basic aspects of the technique for obtaining scientific results within a specific timeframe (Garg, 2016). The study population for this research is working and non-working mothers selected randomly from the children studying in different schools of Gulshan-i-Iqbal, Karachi city. The researcher selected schools based on convenient geographical proximity. A structured questionnaire was selected as a research tool to collect data. This type of research is used to determine central care research (Lydeard, 1991). The questionnaire was distributed to the working and stay at home mothers having children aged between 5-10 years studying in different schools of Karachi city. These mothers were employed in different institutions including hospitals, schools, and the corporate sector. The non-working mothers are full time staying at home mothers. A total of 250 mothers were surveyed through a structured questionnaire. Out of 250 mothers, 160 were working and the remaining 90 were non-working mothers. These mothers filled the questionnaire at the given time within school premises. The researcher took prior permission from the school authority for the availability of small space within the school where meeting with mothers and researcher took held.

\section{Results and Discussions}

This part of the research includes quantitative data and findings along with the discussions. 
Table: 1

Distribution of Respondents according to the working spouse

\begin{tabular}{|l|c|c|c|c|}
\hline Responses & Frequency & Percentage & $\begin{array}{c}\text { Valid } \\
\text { percent }\end{array}$ & $\begin{array}{c}\text { Cumulative } \\
\text { percent }\end{array}$ \\
\hline No & 90 & $36 \%$ & $36 \%$ & $36 \%$ \\
\hline Yes & 160 & $64 \%$ & $64 \%$ & $100 \%$ \\
\hline Grand Total & 250 & $100 \%$ & $100 \%$ & \\
\hline
\end{tabular}

The data clearly shows that $36 \%$ of the respondents are staying at home mothers who are housewives only while the remaining $64 \%$ of women are working women. These working women were doing full-time jobs in different schools, hospitals, and private corporate sector of Karachi city.

Table: 2

Distribution of respondents according to TV watching duration

\begin{tabular}{|l|c|c|c|c|}
\hline Responses & Frequency & Percentage & $\begin{array}{c}\text { Valid } \\
\text { percent }\end{array}$ & $\begin{array}{c}\text { Cumulative } \\
\text { percent }\end{array}$ \\
\hline Up to 1 hour & 96 & $38 \%$ & $38 \%$ & $38 \%$ \\
\hline 1 - 2 hours & 105 & $42 \%$ & $42 \%$ & $80 \%$ \\
\hline 2 -3 hours & 19 & $8 \%$ & $8 \%$ & $88 \%$ \\
\hline more than 3 & 30 & $12 \%$ & $12 \%$ & $100 \%$ \\
\hline Grand Total & 250 & $100 \%$ & $100 \%$ & \\
\hline
\end{tabular}

This data indicates the duration of the watching television among the children of working and non-working mothers which clearly states that $38 \%$ children watch television for 1 hour only, $42 \%$ children are more willingly to watch television for 1-2 hours, $8 \%$ children liked to watch television for $2-3$ hours and $12 \%$ children watch television for more than 3 hours. The more time watching television is the result of a lack of concentration from their mother, which led them to spend more time in front of the television.

Table: 3

Distribution of Respondents according to TV watching timings

\begin{tabular}{|c|c|c|c|c|}
\hline Responses & Frequency & Percentage & $\begin{array}{c}\text { Valid } \\
\text { percent }\end{array}$ & $\begin{array}{c}\text { Cumulative } \\
\text { percent }\end{array}$ \\
\hline Morning & 0 & $0 \%$ & $0 \%$ & $0 \%$ \\
\hline Afternoon & 68 & $27 \%$ & $27 \%$ & $27 \%$ \\
\hline Evening & 117 & $47 \%$ & $47 \%$ & $74 \%$ \\
\hline Night & 21 & $8 \%$ & $8 \%$ & $82 \%$ \\
\hline Anytime & 44 & $18 \%$ & $18 \%$ & $100 \%$ \\
\hline Grand Total & 250 & $100 \%$ & $100 \%$ & \\
\hline
\end{tabular}


The above table shows that the most preferable timing of the children and $47 \%$ majority of them watched at evening, $27 \%$ children want to watch television after returning from school at afternoon, $18 \%$ children don't have any fix allocated time and they watch any time they want whereas only $8 \%$ children watched television at night. It is noticeable that children who watch television without any time restriction are all homemakers' kids. Working mothers children are more strict about the time duration of watching television as their mothers have to wake up early on fixed timing.

Table: 4

Distribution of respondents according to child monitoring by mothers

\begin{tabular}{|c|l|c|c|c|c|}
\hline \multicolumn{2}{|c|}{ Responses } & Frequency & Percentage & $\begin{array}{c}\text { Valid } \\
\text { Percent }\end{array}$ & $\begin{array}{c}\text { Cumulative } \\
\text { percent }\end{array}$ \\
\hline \multirow{2}{*}{$\underset{\nabla}{\nabla}$} & $\begin{array}{l}\text { Yes ( stay at home } \\
\text { mothers) }\end{array}$ & 232 & $93 \%$ & $93 \%$ & $93 \%$ \\
\cline { 2 - 6 } & $\begin{array}{l}\text { No ( working } \\
\text { mothers) }\end{array}$ & 18 & $7 \%$ & $7 \%$ & $100 \%$ \\
\cline { 2 - 6 } & Grand Total & 250 & $100 \%$ & $100 \%$ & \\
\hline
\end{tabular}

The above table shows that $93 \%$ of the stay at home mothers monitor their children when they watch television and only $7 \%$ working mothers replied that they don't monitor their kids when they are watching television as they are not available in the house to monitor their children and also no other elder is also available to look after their kids.

Table: 5

Distribution of respondents according to monitoring methods

\begin{tabular}{|l|l|c|c|c|c|}
\hline \multicolumn{2}{|c|}{ Responses } & Frequency & Percent & Valid percent & $\begin{array}{c}\text { Cumulative } \\
\text { percent }\end{array}$ \\
\hline \multirow{2}{*}{$\begin{array}{l}\text { Keep an eye on what } \\
\text { they watch }\end{array}$} & 179 & $72 \%$ & $72 \%$ & $72 \%$ \\
\hline $\begin{array}{l}\text { By keeping child-lock } \\
\text { for "Elders" channels }\end{array}$ & 12 & $5 \%$ & $5 \%$ & $76 \%$ \\
\cline { 2 - 5 } & $\begin{array}{l}\text { Always watch TV } \\
\text { along with them }\end{array}$ & 48 & $19 \%$ & $19 \%$ & $96 \%$ \\
\cline { 2 - 5 } & No response & 11 & $4 \%$ & $4 \%$ & $100 \%$ \\
\cline { 2 - 5 } & Grand Total & 250 & $100 \%$ & $100 \%$ & \\
\hline
\end{tabular}

The above table shows that $72 \%$ of the stay at home mothers keep an eye when their kids are watching television, $19 \%$ stay at home mothers always watch television along with their kids and only 5\% working mothers monitor their kids by keeping child lock for elders channels as they came late from their workplace 
and they can't monitor their kids constantly. Only $4 \%$ of mothers did not give any response.

Table: 6

Distribution of respondents according to a child talking time with parents

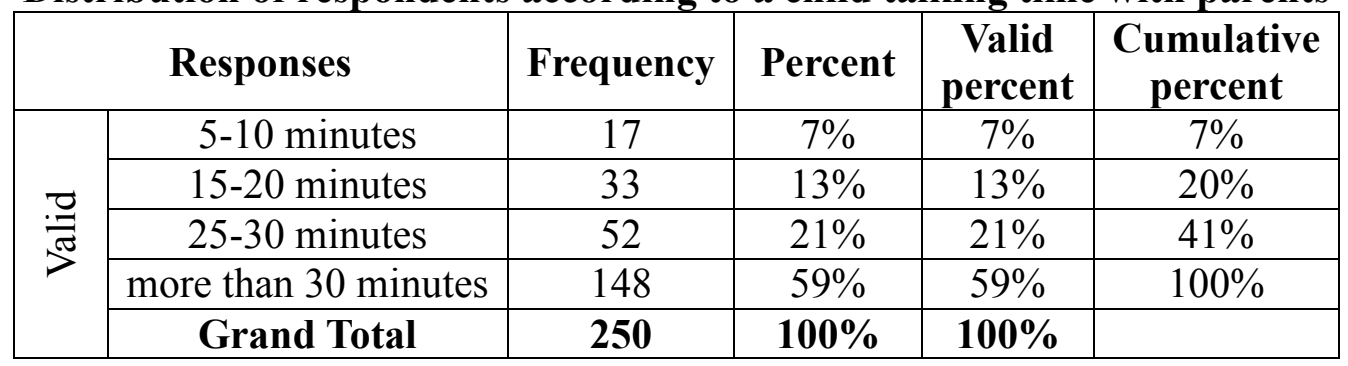

The above table shows that $59 \%$ stay at home mothers especially talk more than 30 minutes with their child, $21 \%$ non-working mothers talk $25-30 \mathrm{mins}$ in a day with their child, $13 \%$ working mothers talk 15-20 minutes in a day and only $7 \%$ working mothers talk 5-10 minutes with their child. This table gave us a brief review about the time management of the mothers with their kids, as it is mentioned above that more time is given by stay at home mothers to their kids as they are 24 hours available to their young ones and listens what they need. In contrast, working mothers have dual responsibilities to tackle all the house chores in limited time therefore; they have fewer minutes to talk especially with their kids.

Table: 7

Distribution of respondents according to parents watching TV with child

\begin{tabular}{|c|l|c|c|c|c|}
\hline \multicolumn{2}{|c|}{ Responses } & Frequency & Percent & $\begin{array}{c}\text { Valid } \\
\text { percent }\end{array}$ & $\begin{array}{c}\text { Cumulative } \\
\text { percent }\end{array}$ \\
\hline \multirow{4}{*}{$: \underset{7}{*} \underset{*}{*}$} & Frequently & 111 & $44 \%$ & $44 \%$ & $44 \%$ \\
\cline { 2 - 6 } & Sometimes & 114 & $46 \%$ & $46 \%$ & $90 \%$ \\
\cline { 2 - 6 } & Rarely & 20 & $8 \%$ & $8 \%$ & $98 \%$ \\
\cline { 2 - 6 } & Never & 5 & $2 \%$ & $2 \%$ & $100 \%$ \\
\cline { 2 - 6 } & Grand Total & 250 & $100 \%$ & $100 \%$ & \\
\hline
\end{tabular}

The above table shows that $46 \%$ of non-working mothers sometimes watch television with their kid, 44\% non-working mothers frequently watch television with their child, $8 \%$ working mothers rarely watch TV with their child whereas only $2 \%$ never watch TV with their kid. 


\section{Discussions}

This study aims to develop a comparative relationship of media exposure, between working and nonworking mothers' children. As Pakistan is a third world country, and to maintain a sustainable lifestyle most of the woman tends to work outside their homes leaving their kids behind. When these children are left alone, their mothers try to make them engage with any medium of media. As Television is the cheaper form of media, it is easier to be available at home. This research found that $36 \%$ stayed at home mothers whereas $64 \%$ were full time working mothers. It was expected that working mothers' kids are more exposed to media as they have no elderly supervision. The results show that $42 \%$ of children watch more than 1-hour television which lasted up to 2 hours also. Only $12 \%$ of kids were severely addicted to watching television for more than 3 hours of working mothers. These kids usually prefer to watch television rather than playing is an option also. It was also observed that the common timings for watching television are usually in the evening, as mothers arrived at home after their work hours hence, $42 \%$ of children watch television in the evening.

Furthermore, findings proved that $93 \%$ stay at home mothers keep an eye on their children when watching television as compared to the nonworking mother who is mostly busy with job chores to be completed on time, and this prevents them to monitor their kids and what they watch on television.

Children are closer to their moms as compare to their fathers, it is human nature. Thus mothers are required to spend more time with their kids but if she is a working lady, it gets very difficult for her to fulfil the emotional and psychological needs of her kids. Similar findings were revealed where only $13 \%$ of working mothers spend 15-20 minutes with their kids. Coviewing is the method of watching television when both kids and parents watch television together. It was assumed primly that working mothers do not get enough time to watch television together with their kids and the same expected results were found that $8 \%$ of working mothers rarely watch television with their kids. The reason was the same as presumed due to the lack of time and burdened with the house and office chores.

\section{Conclusions}

Due to the worldwide economic crisis and rise in the part-time employment culture of mothers of young children has increased a lot not only in Pakistan but all over the world. Over time, mothers are becoming more self-sufficient and independent due to the earning they get. But mothers are more burdened due to workload as they have to cope at home and the workplace also. They have to 
justify their presence at both places and this justification of work may result in neglecting their kids who are more deserving of her love care and affection.

Another way to make busy kids is by engaging them through media. The most common type of media available at almost every house in Pakistan is Television. The television can keep a child busy for many hours; in fact, working mothers have a baby sitter in the form of a television set. Television has its benefits and flaws. Long hours watching television have adverse effects on children resulting in the form of hyperactivity, violence, anger loss of concentration, and many more. This study shows that If mother would not be available at home due to job and working nature her kids would be busier in watching television with uncertain watching hours having no constant and strict time to be followed for watching television. As compared to the stay at home, mothers who keep an eye strictly what kids are watching and how they are behaving after having exposure with media. The major finding this research reveals that $64 \%$ were working mothers who were employed in different private and government sectors of Karachi city who were working as primary teachers, college lecturers, and part-time working ladies in the corporate sector of Karachi city. The other finding also proves that working mothers' kids are stricter about timing allocated for watching television, $42 \%$ of children of working mothers watch television for 1-2 hours. The reason for being strict about television timings is their mother has to go at a specific time to her workplace. She has to wake up on time her all house chores have to be done according to her workplace timing schedule and this makes her children more punctual about timings. It was also found in this research that $47 \%$ of children normally watch television in the evening because most of the children woke up after taking a nap in the afternoon and watch television in the evening. Working mothers also allow their kids to watch television in the evening when they arrive from their workplace. This study also reveals different methods for keeping an eye on children. $72 \%$ keep an eye on their children as mothers have a prime responsibility to look after their kids while $5 \%$ working mothers tend to lock inappropriate channels for kids as they are not fully available to their young ones.

\section{Recommendations}

The following recommendations are given to control media exposure among children.

- The joint family system should be promoted to support the working woman

- PEMRA( Pakistan electronic media regulatory authority) should promote child-friendly channels according to their age and gender needs

- Working mothers should be provided with maternal leaves, which helps them to take care of their children more appropriately. 
- Mothers should spend more time talking with their kids, this will promote a friendly bond between them

- If a mother is a working spouse, she must ensure to lock all the elderly channels, so a child won't be able to watch any elderly content

- Media time restriction should be followed strictly in the houses either mother is staying at home or working mother.

- Television should be placed at the center place of the house so that the mother can keep an eye on what their children are watching.

- Co viewing of television should be promoted in the house. This will helps to create a friendly environment in the home and children won't hesitate to discuss any question in their little minds.

\section{References}

Almani, A. S., Abro, A., \& Mugheri, R. A. (2012). Study of the Effects ofWorkingMothers on the Development of Children in Pakistan. InternationalJournal of Humanities and Social Science, vol.2:11, pp.164-171.

Ansari, A. \& Crosnoe, R. (2016). Children's Hyperactivity, Television Viewing, and the Potential for Child Effects. Children and Youth Services Review, vol.61, pp.135-140.

Baum II, C. L. (2003). Does Early Maternal Employment Harm Child Development? An Analysis of the Potential Benefits of Leave Taking. Journal of Labor Economics, vol.21:2, pp.409-448.

Brown, A. \& Council on Communications and Media Executive Committee.(2011). Media Use by Children Younger than 2 Years. Pediatrics, vol.128:5, pp.1040-1045. https://doi.org/10.1542/ peds.2011-1753

Brown, J. E., Broom, D. H., Nicholson, J. M. \& Bittman, M. (2010). Do Working Mothers Raise Couch Potato Kids? Maternal Employment and Children's Lifestyle Behaviours and Weight in Early Childhood. Social Science \&Medicine, vol.70:11, pp.1816-1824.

Cohany, S., Sok, E. (1998). Trends in Labor Force Participation of Married Mothers with Infants. Monthly Labor Review, vol.130,pp.1-15.

David Pelcovitz, Ph. D. January 9, 2013 https://www.ou.org/life/parenting/notefrom-dr-pelcovitz-on-impact-working-mothers-on-child-developmentdavid-pelcovitz/ 
Dex, S. \& Joshi, H. (eds) (2005). Children of the Twenty First Century: From Birth to Nine Months, Bristol, Policy Press .Dex, S. and Joshi, H. (eds) (2005), Children of the Twenty First Century: From Birth to Nine Months, Bristol, Policy Press .

Drabman, R. S. \& Thomas, M. H. (1974). Does Media Violence Increase Children's Toleration of Real-Life Aggression?.DevelopmentalPsychology,vol.10:3, p.418.

Duncan, G. J., Brooks-Gunn, J., Yeaung, W. J., Smith, J. R. (1998). How Much Does Childhood Poverty Affect the Life Chances of Children? American Sociological Review, vol.63, pp.406-423.

Einhorn, L. J. (1992). Abraham Lincoln, the Orator: Penetrating the Lincoln Legend: Greenwood Press Westport.

Essays, U. (2018). The Life of Working Mothers In Pakistan Social Work Essay. Retrieved from https://www.ukessays.com/essays/social-work/the-life-ofworking-mothers-in-pakistan-social-work-essay.php? vref $=1$.

Garg, R. (2016). Methodology for Research I. Indian Journal of Anaesthesia, vol.60:9, p.640.

Guryan, J., Hurst, E. \& Kearney, M. (2008). Parental Education and Parental Time with Children. Journal of Economic Perspectives, vol.22:3, pp.23-46.

Hawkes, C. (2007). Promoting Healthy Diets and Tackling Obesity and DietRelated Chronic Diseases: What are the Agricultural Policy Levers? Food and Nutrition Bulletin, vol.28(2_suppl2), pp.S312-S322.

Hoffman, L., Hoffman, L. N. W. \& Youngblade, L. (1999). Mothers at Work:Effectson Children's Well-Being: Cambridge University Press.

Jordan, A. (2004). The Role of Media in Children's Development: An Ecological Perspective. Journal of Developmental \& Behavioral Pediatrics, vol.25:3, pp.196-206.

Joshi, H. \& Verropoulou, G. (2000), Maternal Employment and Child Outcomes, Occasional Paper, London, The Smith Institute.

Kisker, E. \& Maynard, R. (1995), 'Quality, Cost and Parental Choice of Child Care', in Blau, D. (ed.), The Economics of Childcare, New York, Sage . 
Leibowitz, A. (1977). Parental Inputs and Children's Achievement. The Journal of Human Resources, vol.12:2, pp.242-251.

LYDEARD, S. (1991). The Questionnaire as a Research Tool. Family Practice, vol.8:1, pp.84-91.

Mayer, S. (1997). What Money Can’t Buy: Family Income and Children's Life Chances Cambridge, MAHarvard University Press.

Milne, A. M., Myers, D. E., Rosenthal, A. S., \& Ginsburg, A. (1986). Single Parents, Working Mothers and the Educational Achievement of School Children. Sociology of Education, vol.59:3, pp.125-139.

Mohajan, H. K. (2018). Qualitative Research Methodology in Social Sciences and Related Subjects. Journal of Economic Development, Environment and People, vol.7:1, pp.23-48.

Morowatisharifabad, M. A., Karimi, M. \& Ghorbanzadeh, F. (2015). Watching Television by Kids: How Much and Why? Journal of Education and Health Promotion, vol.4:36, pp.1-6.

Motro, J. \& Vanneman, R. (2015, December). The 1990s Shift in the Media Portrayal of Working Mothers. In Sociological Forum, vol.30:4, pp.1017-1037.

Ordway, D.-M.(2018). Working-Mother-

Employment.https://journalistsresource.org/studies/economics/jobs/workin g-mother-employment-research/.

Paré, E. R. \& Dillaway, H. E. (2005). 'Staying at Home'versus' Working': A Call for Broader Conceptualizations of Parenthood and Paid Work. Michigan Family Review, vol.10:1, pp.66-87.

Poduval, J. \& Poduval, M. (2009). Working Mothers: How Much Working, How Much Mothers and where is the Womanhood? Mens Sana Monographs, vol.7:1, p.63.

Ray, M. \& Jat, K. R. (2010). Effect of Electronic Media on Children. Indian Pediatrics, vol.47:7, pp.561-568.

Scarr, S., Phillips, D. \& McCartney, K. (1989). Working Mothers and their Families. American Psychologist, vol.44:11, p.1402. 
Sherlock, R. L., Synnes, A. R. \& Koehoorn, M. (2008). Working Mothers and Early Childhood Outcomes: Lessons from the Canadian National Longitudinal study on children and youth. . Early Human Development, vol.84:4, pp.237-242.

Strasburger, V. C., Jordan, A. B. \& Donnerstein, E. (2010). Health Effects of Media on Children and Adolescents. Ped Brown, A. \& Council on Communications and Media Executive Committee. (2011).

Welch, G. L. (1996). Parenting and Television: An Investigation of Factors Related to Mothers' Knowledge of Children's Television Viewing. Oklahoma State University.

Zick, C. D., Bryant, W. K. \& Österbacka, E. (2001). Mothers' Employment, Parental Involvement and the Implications for Intermediate Child Outcomes. Social Science Research, vol.30:1, pp.25-49.

Zimmerman, F. J. \& Christakis, D. A. (2005). Children's Television Viewing and Cognitive Outcomes: ALongitudinal Analysis of National Data. Archives of Pediatrics \&Adolescent Medicine, vol.159:7, pp.619-625.

Wajiha Raheeq is a Ph.D. Scholar in the Department of Social Work, University of Karachi, Karachi, Pakistan.

Dr. Muhammad Arshad is an Assistant Professor in the Department of Social Work, University of Karachi, Karachi, Pakistan. 